\title{
Flyer thuistesten bij aanvallen
}

De gouden standaard voor het stellen van een diagnose epilepsie of psychogene niet-epileptische aanvallen is het zien van een representatieve aanval tijdens een video-EEGregistratie. In veel gevallen blijkt het registreren van een aanval tijdens een video-EEG-registratie niet mogelijk, bijvoorbeeld vanwege een lage aanvalsfrequentie. Daarom hebben thuisvideo's vaak een cruciale rol als aanvulling op een anamnese, hetero-anamnese en interictaal EEG bij het vaststellen van de juiste diagnose. Helaas blijkt in de praktijk de kwaliteit van de thuisvideo vaak matig, waardoor beoordeling van de aanval moeilijk blijft. Veel voor- komende oorzaken zijn praktisch van aard zoals het onvolledig in beeld brengen van de patiënt, onvoldoende verlichting, een overmaat aan achtergrondgeluiden, onvoldoende interactie met de patiënt. Deze flyer beoogt de kwaliteit van deze thuisvideo's te vergroten door eenvoudige instructies over de opname aan de filmer, meestal een familielid of een begeleider van de patiënt. Ook wordt aan de filmer gevraagd enkele eenvoudige testvragen te stellen aan de patiënt. Onze ervaring is dat zowel de kwaliteit van de opname als van de interactie met de patiënt aanzienlijk verbetert als deze eenvoudige adviezen worden opgevolgd.

\section{国S汪 IN}

Stichting Epilopsie Instellingen Nederiond

\section{Filmen en testen van aanvallen in de thuissituatie}

Om een beter beeld te krijgen van de aanvallen, van uzelf, uw kind, uw naaste of cliënt, heeft de behandelend arts gevraagd een aanval op beeld vast te leggen. De aanval kan gefilmd worden met een camera of mobiele telefoon. Stel tijdens het filmen een aantal korte en eenvoudige vragen. Dit geeft, naast de beelden, nog meer informatie over het type aanval en de veranderingen in het bewustzijn tijdens en na de aanval.

\section{Tips voor het filmen}

Probeer ervoor te zorgen dat uw kind, naaste of cliënt goed in beeld is. Soms is het nodig dat er wordt ingezoomd op afzonderlijke delen van het lichaam die bij de aanval zijn betrokken. Daarnaast is het belangrijk dat er voldoende licht is in de ruimte waar de opnames worden gemaakt. Maak opnames met uw rug naar de lichtbron, dus film niet tegen de zon in of in de richting van een lamp of raam.

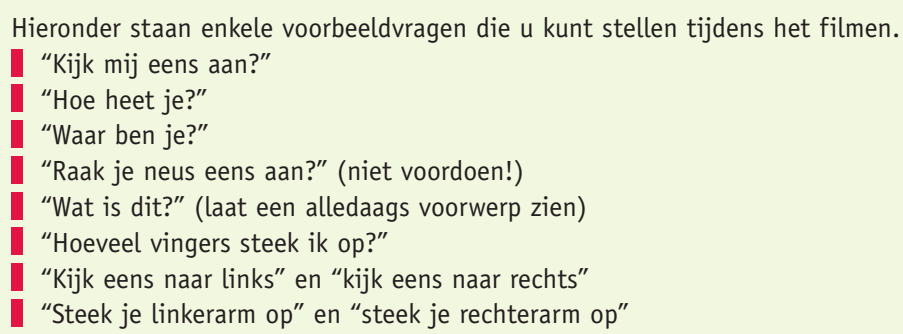

Probeer deze vragen te herhalen tot de aanval over is en degene die wordt gefilmd weer normaal reageert. Vertel tijdens het filmen hardop wat u ziet en hoort (zoals verandering van gelaatskleur, oogstand, klamheid, geluiden, ademhaling, of hij/zij correct op de vragen antwoordt etc.).

Indien mogelijk, beschrijft $u$ de aanval dan ook zo gedetailleerd mogelijk op papier. Noteer in de aanvalsbeschrijving ook de datum, het tijdstip, de omstandigheden (bijvoorbeeld tijdens slaap of inspanning etc.) en duur van de aanval.

De beelden geven, samen met deze korte en eenvoudige vragen, veel extra informatie over de aanvallen. We vragen $u$ de beelden bij het eerstvolgende consult met uw arts mee te nemen op een USB-stick of CD. 